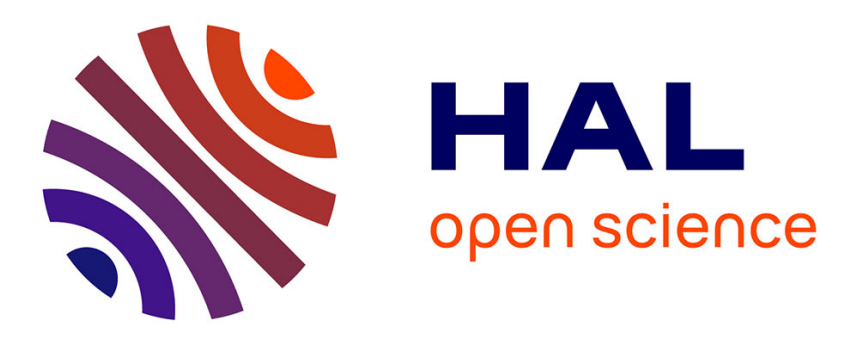

\title{
A Power Electronic based Transformer for Feeding Sensitive Loads
}

H. Iman-Eini, Jean-Luc Schanen, S.H. Farhangi, Jean Barbaroux, Jean-Pierre

Keradec

\section{- To cite this version:}

H. Iman-Eini, Jean-Luc Schanen, S.H. Farhangi, Jean Barbaroux, Jean-Pierre Keradec. A Power Electronic based Transformer for Feeding Sensitive Loads. Power Electronics Specialists Conference PESC 08, Jun 2008, Rhodes, Greece. hal-00289712

\section{HAL Id: hal-00289712 \\ https://hal.science/hal-00289712}

Submitted on 13 Feb 2009

HAL is a multi-disciplinary open access archive for the deposit and dissemination of scientific research documents, whether they are published or not. The documents may come from teaching and research institutions in France or abroad, or from public or private research centers.
L'archive ouverte pluridisciplinaire HAL, est destinée au dépôt et à la diffusion de documents scientifiques de niveau recherche, publiés ou non, émanant des établissements d'enseignement et de recherche français ou étrangers, des laboratoires publics ou privés. 


\title{
A Power Electronic Based Transformer for Feeding Sensitive Loads
}

\author{
H. Iman-Eini ${ }^{1,2}$, JL. Schanen ${ }^{2}$, Sh. Farhangi ${ }^{1}$, J. Barbaroux ${ }^{2}$, JP. Keradec ${ }^{2}$ \\ 1: School of Electrical and Computer Engineering, University of Tehran, Tehran, Iran \\ 2: G2ELab, ENSIEG B.P.46, 38402 St Martin d'Heres cedex, France
}

\begin{abstract}
In this paper a modular power electronic transformer (PET) for feeding sensitive loads is presented. The proposed PET can be directly connected to the medium voltage levels and provide a low-voltage and highly-stable interface with the consumer applications. At the input side, cascaded $\mathrm{H}$-bridge rectifier serves as an active-front-end (AFE) rectifier to ensure sinusoidal input current, while converting $\mathrm{AC}$ input voltage to distinct $\mathrm{DC}$ buses. The isolated DC/DC converters are connected to the individual DC buses and reduce the AC voltage level through series-input and parallel-output configuration of the H-bridge cells. The proposed PET can compensate both the active and reactive powers, and remove the power quality disturbances such as sag, swell, under voltage, over voltage and voltage flicker. In comparison to the conventional transformers, it has low weight, compact volume, extended functionality, and eliminates the necessity for toxic dielectric coolants. The proposed topology and the principle of operation are explained and the validity of the design is verified using the simulation and experimental results.
\end{abstract}

\section{INTRODUCTION}

In recent years, significant advances in power semiconductor device technology, low-cost, high-speed control processors, and matured PWM algorithms have led to a number of modern power converter topologies. A new type of transformers based on Power Electronics (PE) has been introduced, which realizes voltage transformation, galvanic isolation, and power quality enhancements in a single device. The PE based transformer provides a fundamentally different and more complete approach in transformer design by using power electronics on the primary and secondary sides of the transformer. Several integrated PQ features such as instantaneous voltage regulation under load dynamics and transients, voltage sag compensation, power factor correction, and harmonic suppression can be incorporated into PET, thanks to the application of power electronics technology.

For realizing the PET, different topologies in literature have been presented [1-9]. In [1], the AC/AC buck converter has been proposed to transform the voltage level directly and without any isolation transformer. This method is perhaps the most direct approach to single phase AC power conversion, but, it would cause the semiconductor devices to bear very high stress. In [2- 4], the concept of a high-frequency AC/AC link, termed as electronic transformer, have been proposed. In this approach, the line side $\mathrm{AC}$ waveform is modulated into a
High Frequency (HF) square wave, coupled to the secondary of HF transformer, and again is demodulated to AC form by a synchronous converter. This method however does not provide any benefits in terms of control or power-factor improvement, and may not protect the critical loads from the momentary power interruptions due to lack of energy storage system.

Another approach is a three-part design that utilizes an input stage, an isolation stage, and an output stage, addressed in [5-7]. These approaches enhance the flexibility and functionality of the electronic transformers owing to the available DC links. In [5], for operating properly in medium voltage levels, the series to parallel connection of converters has been used. The number of series converters depends on voltage levels and the type of semiconductors. In [7], a topology based on back-toback diode-clamp multilevel converter has been introduced. This approach can perform different power quality functions and provide galvanic isolation. However, the modularity and scaling to different voltage and power levels is not straightforward.

In [8], a classification system for three-part structures has been proposed. A description and analysis of the power flow and energy balance characteristics of multicellular converters has been also presented. The proposed method, however, does not provide full current control and power factor correction at the input side.

In [9], a new AC/AC multilevel converter family has been presented. The presented Modular Multilevel Line side Converter $\left(\mathrm{M}^{2} \mathrm{LC}\right)$, applied to $\mathrm{AC}$-fed traction vehicles, enables additional advantages. In this application, the elimination of the bulky line transformer, increased efficiency, as well as a significantly improved transient behavior of the converter system is achieved.

In [10-11], novel multilevel line side converter sections based on cascaded H-bridge converter have been proposed. These converters can replace the heavy and bulky line side transformers in electric trains. In these topologies, a series connection of $\mathrm{H}$-bridge cells is used to reduce the high input voltage level.

The focus of this paper is to realize a MV-to- $\mathrm{LV}$ power electronic transformer as a power delivery component to supply sensitive loads. Therefore, a new modular transformer based on Cascaded H-Bridge rectifier $(\mathrm{CHB})$ is presented. The proposed approach is extremely modular, performs conventional transformer functions, and satisfies the desired PQ requirements. The novelty of this approach is related to the $\mathrm{CHB}$ rectifier, 
where it maintains DC voltage balancing across the primary DC buses. Hence, the independent loads can be connected to the converter (see Fig. 4). The validity of this approach is verified by simulation and experimental results on a laboratory scale prototype.

\section{PRINCIPLE OF OPERAT ION}

\section{A. Electronic Transformer Using HF AC-link}

Fig. 1 shows the basic block diagram of the electronic transformer using HF AC-link. In this scheme, the line side $\mathrm{AC}$ waveform is modulated with a static converter to a high-frequency square-wave and passed through a HF transformer and again with a synchronous converter, it is demodulated to AC form. Since the transformer size is inversely proportional to the frequency, the highfrequency transformer will be much smaller than the linefrequency transformer. So, the transformer size, weight and stress factor is reduced noticeably. This scheme can be utilized to mitigate power-line disturbances such as voltage sags and swells in low voltage equipments.

In this approach, four-quadrant power switches are needed, which presents difficulties in turning off inductive load current because of the absence of a freewheeling path in the switches [4]. Also, to operate at the medium voltage levels, a series-tided connection of power switches is needed, which are often difficult to control and to command. Another drawback is the inability to prevent primary voltage harmonics from propagating into the load side. In addition, this converter does not provide any benefits in terms of control or power-factor improvement, and may not protect the critical loads from the momentary power interruptions due to lack of energy storage system.

\section{B. Power Electronic Based Transformer with DC Link}

Fig. 2 shows the basic block diagram of a power electronic based transformer (PET) which includes three parts. First part or the input stage is an AC/DC converter which is utilized to shape the input current, to correct the input power factor, and to regulate the voltage of primary DC bus. Second part is an isolation stage which prepares the galvanic isolation between the primary and secondary system. In this part, the DC voltage is converted to a high-frequency square-wave signal, coupled to the secondary of the HF transformer and is rectified to form the DC link voltage. The last part is a voltage source inverter which regenerates the desired $\mathrm{AC}$ waveforms.

In comparison to first method, the voltage or current of PET can be flexibly controlled through Pulse Width Modulation (PWM) in either side. It is possible to add energy storage to enhance the ride-through capability of the PET or to prepare integrated interface for distributed resources due to the available DC links. It prevents the voltage or current harmonics to propagate in either side of the transformer, even if the input voltage has low order harmonic content or the load is not linear. Each part of PET can be made based on the well known multilevel converters and optimized for high-voltage or high-power applications. Thus, this structure will be probably the mainstream of the future PET [12].

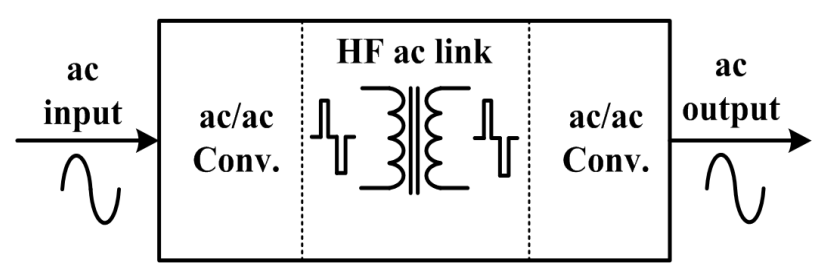

Figure 1. Block Diagram of electronic transformer using HF AC link

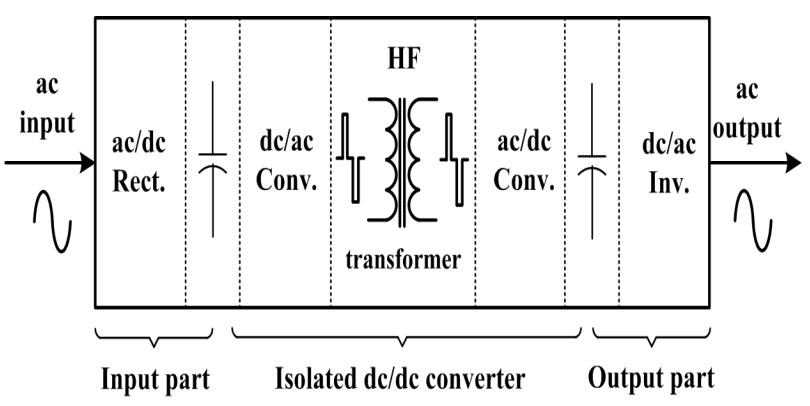

Figure 2. Block Diagram of Power Electronic based Transformer (PET) with DC link

\section{PROPOSED CONFIGURATION}

In this paper, a three-part design is introduced. It is a new configuration based on the cascaded H-bridge rectifier shown in Fig. 3. In first part, a hybrid stepped and PWM modulation is employed to improve the converter efficiency and the functionality, in comparison to [5]. The proposed approach is extremely modular, easy to implement, and can be extended for an arbitrary number of voltage-levels. Further, it does not have packaging and physical layout difficulties when the number of voltage levels increases beyond five or six (compared to the multilevel converter discussed in [7]).

The modular converter in Fig. 3 composed of $\mathrm{N}$ individual converter cells, connected in series on the primary side and in parallel on the secondary side. Each converter cell consists of an H-bridge AC-to-DC chopper on the line side to rectify the AC voltage and to stabilize the DC link voltage on the primary side of the individual converter sections. The second part of the converter cells is formed by a DC-to-DC converter. This part of the converter cell contains the HF transformer with the high insulation capability. On the secondary side conventional voltage source inverters or motor drives (which can be part of the respective load) are connected. This stage generates the symmetric three-phase voltages with the desired amplitude and frequency.

The PE based transformer shown in Fig. 3 is extremely modular, easy to implement, and can be extended for an arbitrary number of voltage-levels. It is an advanced power electronic system replacement for conventional transformers. It can provide alternative customer service options, such as DC, 50, 60 or 400-hz AC power (for communications applications). It performs PQ functions, such as sag correction, reactive power compensation and is capable to provide three-phase power from a single-phase line. It will have remote communication capability and monitoring capability in the distribution system of the future. 


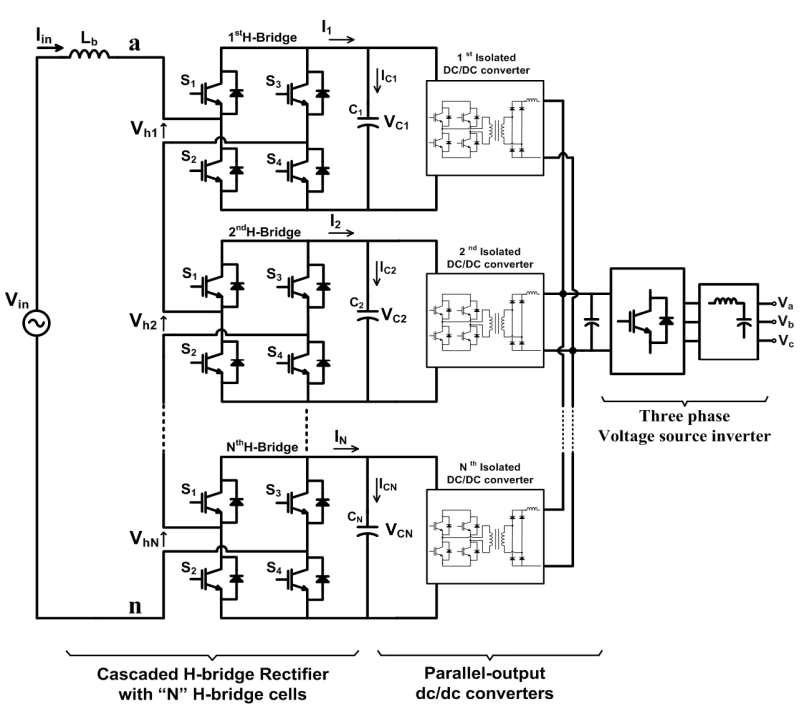

Figure 3. Proposed structure of the power electronic transformer (PET) based on $\mathrm{CHB}$ rectifier

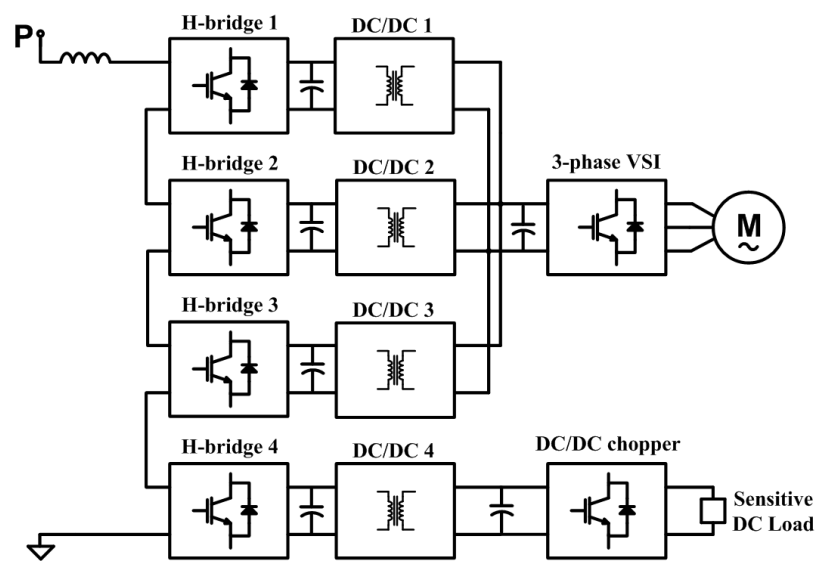

Figure 4. MV-to-LV AC/DC converter feeding a three-phase AC load and a sensitive DC load

The proposed MV-to-LV AC/DC converter in Fig. 3 can be reconfigured to supply different type of electric loads simultaneously. This capability is shown in Fig. 4, where the $\mathrm{AC} / \mathrm{DC}$ rectifier supplies a three-phase voltage source inverter and a DC/DC chopper feeding a sensitive load. In this case, the electric power which is delivered to the series-connected $\mathrm{H}$-bridge cells would be different. Thereby, the CHB rectifier control should maintain voltage balance among the primary DC links, even if the loads attached to the converter cells are different. Another challenging issue relates to the equal load current sharing among the parallel cells. A little voltage offset at the input side of parallel-output cells can cause a large current deviation. This problem, in practice, can be intensified due to the non-ideality of parallel cells.

\section{CONTROL OF POWER ELECTRONIC TRANSFORMER}

The power electronic transformer has three stages and each stage can be controlled independently from the other one. In this section the appropriate controllers for the
CHB rectifier and the isolation stage are presented, respectively.

\section{A. Control of $\mathrm{CHB}$ Converter}

The main challenges associated with the CHB rectifier control are shaping the input current, controlling the input power factor, and keeping the DC link voltages at the desired reference value. The CHB converter, in the rectification mode, aims to achieve $\mathrm{N}$ equal $\mathrm{DC}$ voltages across the capacitors $\left(\mathrm{C}_{1}\right.$ to $\left.\mathrm{C}_{\mathrm{N}}\right)$. However, this can become difficult if the loads attached to the cells are not equal, or the series H-bridges have slightly different characteristics. When implementing very high voltage converters, even the parasitic stray capacitances to earth can lead to unwanted scaling effects and leads to unequal voltage distribution among the series connected converters.

Fig. 5 shows the basic block diagram of the proposed controller. It consists of the analog and digital parts. The analog controller generates the Pulse Width Modulated (PWM) signal, Q, and aims to shape the input current, regulate the total voltage of DC links to the reference value, i.e., $\sum \mathrm{V}_{\mathrm{Ci}}=\mathrm{N} \cdot \mathrm{V}_{\mathrm{C}}$, and to control the input power factor.

The digital controller provides voltage balancing across the DC link capacitors. This controller determines the appropriate switching functions, $h_{1}$ to $h_{N}$, for the series-connected H-bridge cells. Each switching function $\mathrm{h}_{\mathrm{i}}(\mathrm{i}=1, \ldots, \mathrm{N})$ corresponds to four operating modes: " 0 ", " $+1 "$, " $-1 "$, and PWM. The switching functions are determined by the digital controller and are applied to the H-bridge cells. The operating mode " 0 " corresponds to the conduction of bottom switches $\left(S_{2}, S_{4}\right)$. In modes " +1 " and " 1 " the diagonal switches $\left(\mathrm{S}_{1}, \mathrm{~S}_{4}\right)$ and $\left(\mathrm{S}_{2}, \mathrm{~S}_{3}\right)$ are turned on, respectively. In PWM mode, the gate signals, $\mathrm{g}_{1}$ to $\mathrm{g}_{4}$, drive the corresponding cell. These signals are obtained from $\mathrm{Q}$, the output of analog controller, as follows:

$$
\begin{array}{ll}
g_{1}=V \bar{Q}, & g_{2}=\overline{V \bar{Q}} \\
g_{3}=\bar{V} Q, & g_{4}=\overline{\bar{V} Q}
\end{array}
$$

where $\mathrm{V}$ is the sign of input voltage and is one if the input voltage is positive; otherwise it is zero.

To take advantage of both low frequency (stepped modulation) and high frequency (PWM) modulation techniques, we employ the hybrid modulation method shown in Fig. 6 [13]. In this method, the input voltage $V_{\text {in }}$ is divided into equal sections with the scale of $\mathrm{V}_{\mathrm{C}}\left(\mathrm{V}_{\mathrm{C}}\right.$ is the reference of primary DC links). Now we define the voltage region $\mathrm{K}$ as follows (see Fig. 6):

$$
(K-1) \cdot V_{C}<\left|V_{\text {in }}\right|<K \cdot V_{C}, K=1, \ldots, N
$$

Region $\mathrm{K}$ is where the magnitude of input voltage, $\left|V_{\text {in }}\right|$, lies between $(K-1) V_{C}$ and $K V_{C}$. Note that the minimum number of cells to synthesize the multilevel waveform, $\mathrm{V}_{\mathrm{an}}$, is equal to the closest integer greater than $\left(\mathrm{V}_{\mathrm{m}} / \mathrm{V}_{\mathrm{C}}\right)$, where $\mathrm{V}_{\mathrm{m}}$ is the peak input voltage. The following benefits can be achieved by utilizing the hybrid modulation technique: 


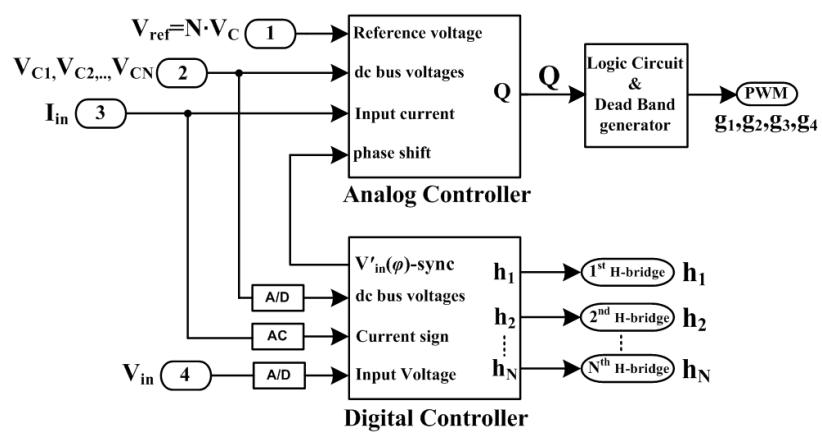

Figure 5. Block diagram of the proposed controller for CHB converter

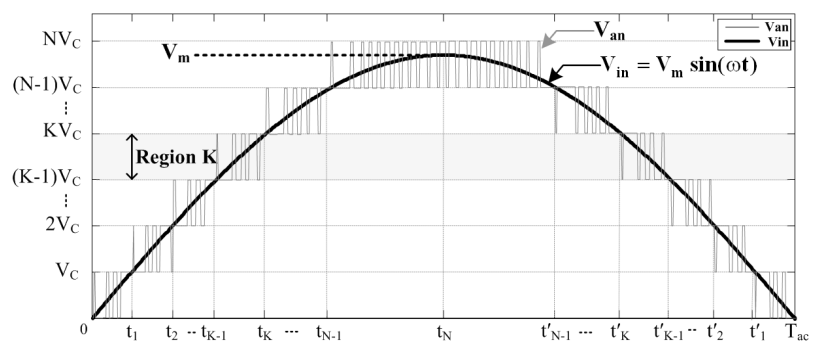

Figure 6. Definition of voltage regions for $K=1, \ldots, N$

- Considerable reduction in size and volume of the input inductance $\mathrm{L}_{\mathrm{b}}$; because the input inductance will not tolerate voltage more than $\mathrm{V}_{\mathrm{C}}$.

- Reduction in THD and EMI at the input side.

- Low switching loss; because at each time only one cell works in high frequency switching mode.

The digital controller performs the control algorithm to maintain the voltage balancing across the DC link capacitors, while the analog controller regulates the sum of DC link voltages to $\mathrm{N} \cdot \mathrm{V}_{\mathrm{C}}$. The proposed control rules, defined hereafter, aims to synthesize the waveform shown in Fig. 6 and to maintain the voltage balancing at the primary DC sides.

1. If $\mathrm{V}_{\text {in }}>0, \mathrm{I}_{\text {in }}>0$, and the voltage region is $\mathrm{K}$, then (K-1) cells with the lowest DC bus voltage are chosen to be charged in mode " +1 ", the $\mathrm{K}^{\text {th }}$ cell in PWM mode, and the rest in mode " 0 ".

2. If $\mathrm{V}_{\text {in }}>0, \mathrm{I}_{\mathrm{in}}<0$, and the voltage region is $\mathrm{K}$, then (K-1) cells with the highest DC bus voltage are chosen to be discharged in mode " +1 ", the $\mathrm{K}^{\text {th }}$ cell in PWM mode, and the rest in mode " 0 ".

3. If $\mathrm{V}_{\text {in }}<0, \mathrm{I}_{\text {in }}>0$, and the voltage region is $\mathrm{K}$, then (K-1) cells with the highest DC bus voltage are chosen to be discharged in mode "- 1 ", the $\mathrm{K}^{\text {th }}$ cell in PWM mode, and the rest in mode " 0 ".

4. If $\mathrm{V}_{\text {in }}<0, \mathrm{I}_{\text {in }}<0$, and the voltage region is $\mathrm{K}$, then (K-1) cells with the lowest DC bus voltage are chosen to be charged in mode "- 1 ", the $\mathrm{K}^{\text {th }}$ cell in PWM mode, and the rest in mode " 0 ".

To perform the above rules, the digital controller takes the voltage and current samples with the sampling frequency $f_{0}$. Then, the region of input voltage, $K$, is updated according to (3), the control algorithm is performed, and the appropriate switching functions, $\mathrm{h}_{1}$ to
$\mathrm{h}_{\mathrm{N}}$, are determined. The switching functions are applied to the H-bridge cells and the corresponding operating modes are selected by the multiplexers. This procedure is repeated in the next sampling periods. As a result, the voltage of each capacitor is controlled by adjusting the charging and discharging times over a mains half-cycle.

\section{B. Control of the Parallel-Output Converter Cells}

The controller of the parallel-output converters has two main functions: regulation of the secondary output voltage $\left(\mathrm{V}_{\mathrm{o}}\right)$ and the load current sharing among the parallel converters. In practice, when $\mathrm{N}$ ideal DC/DC converters are paralleled at the output side, the load current is divided equally among them. However, a very small mismatching among DC/DC converters can lead to unbalanced sharing of the load current. The main sources of mismatching are the transformers turn ratio, the input voltage DC offsets, and mismatching among the cells equivalent series resistances. Although this issue will not lead to instability and runaway condition in the modular structure (due to the presence of $\mathrm{CHB}$ rectifier control), it will cause some problems in terms of thermal management and life time of the parallel converters. To guarantee equal load current sharing and voltage regulation, we employ the controller shown in Fig. 7(a). This controller uses a voltage control loop and $\mathrm{N}$ similar current control loops.

The current controllers are used to control the average current of the parallel cells against the primary DC bus perturbations and the components mismatching. As it can be seen from Fig. 7(a), the inductor current, $i_{k}$, of the $k^{\text {th }}$ cell is sensed and scaled to the proper magnitude. Then, it passes through a low pass filter. This filter is utilized to limit the loop bandwidth and also to decrease the noise power. The filter output is compared with the reference current $\left(i_{r e f}\right)$ generated by the voltage controller. The error signal is entered to the PI regulator and its output determines the switching duty cycle $\mathrm{d}_{\mathrm{k}}$.

According to the modeling method presented in [14], the open-loop transfer function of the inner loops in Fig. 7(a) is computed as follows (see Fig. 7(b)):

$$
G_{i}(s) H_{i}(s)=\frac{m V_{C} \cdot k_{i}}{V_{P} r} \frac{1}{\left(\frac{L}{r} s+1\right) \cdot\left(s / s_{o}+1\right)}
$$

where $\mathrm{V}_{\mathrm{C}}$ is the primary $\mathrm{DC}$ bus voltage, $\mathrm{m}$ the transformer turn ratio, $\mathrm{k}_{\mathrm{i}}$ feedback attenuation gain, $\mathrm{V}_{\mathrm{p}}$ the peak saw-tooth signal, $r$ the equivalent series resistance, $\mathrm{L}$ the filter inductance, and $\mathrm{s}_{\mathrm{o}}$ is the feedback cut-off frequency. Equation (19) shows a second-order system with two stable poles. Thus, a simple PI controller can be used to increase the phase margin and can also serve to shape the loop transfer function in order to achieve a desired transient response.

The voltage controller is used to regulate the output voltage of parallel converters while the input voltage of different cells are regulated by the cascaded $\mathrm{H}$-bridge rectifier, i.e., $V_{1}=V_{2}=\cdots=V_{N}=V_{C}$. 


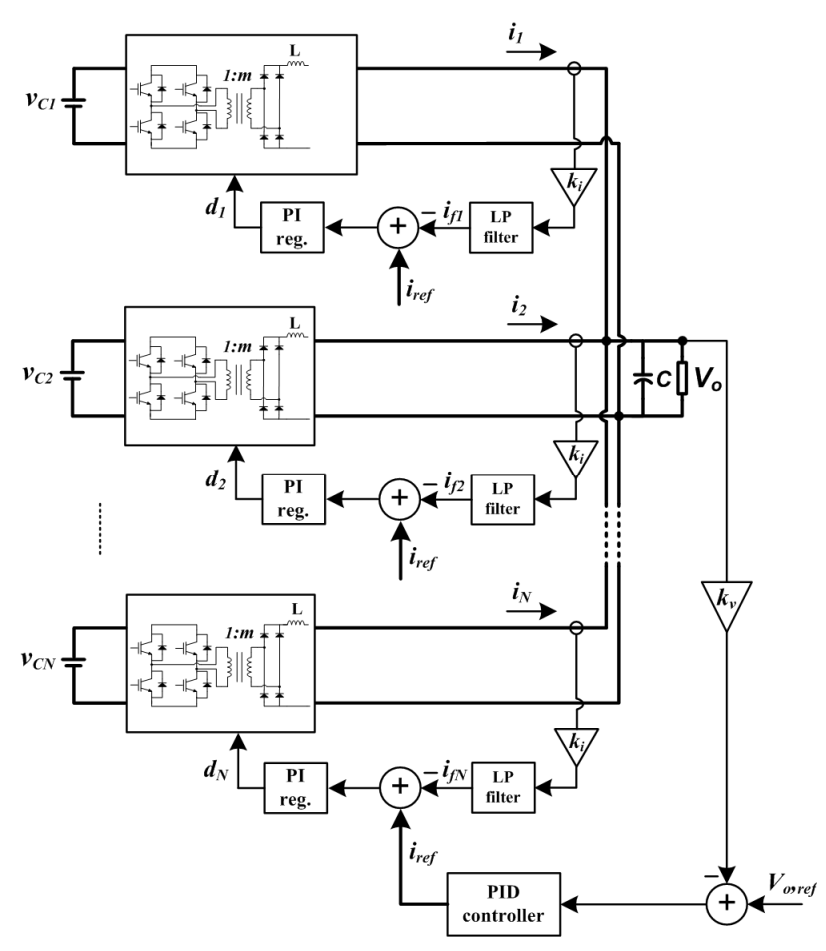

Figure 7(a). Proposed scheme for control of parallel-output cells

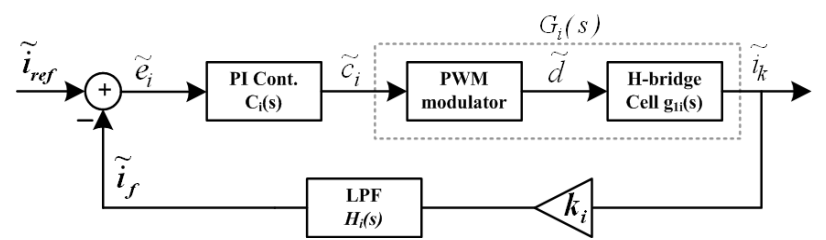

Figure 7(b). Close-loop small-signal model of the $k^{\text {th }}$ cell in Fig. 7(a)

It is worth noting that the mismatching effects and the input voltage offsets are considered as input DC offset and the proposed current control loops will cancel the DC offsets and provide the equal DC operating points for all cells. Additional details about the modeling and design of voltage control loop can be found in [14].

\section{VERIFYING THE PET PERFORMANCE BY SIMULATION AND EXPERIMENTAL RESULTS}

The configuration which has been chosen to verify the PET performance is a $30 \mathrm{~kW}$, single-phase to three-phase transformer $(3.3 \mathrm{kV}$ to $380 \mathrm{~V})$ with four series-connected $\mathrm{H}$-bridge cells at the input side (see the structure in Fig. 3 ). The computer simulations are carried out using MATLAB/SIMULINK program, with the system data given in Table I.

The first simulation investigates the PET performance under voltage sag condition. In this simulation, a 50\% voltage sag appears in the primary voltage at $\mathrm{t}=0.2 \mathrm{~s}$ and lasts $200 \mathrm{~ms}$. The load power is constant and equal to 30 $\mathrm{kW}$. The simulation results are shown in Fig. 8 and Fig. 9.

Fig. 8 illustrates the waveforms of the input voltage and the output phase voltage, and Fig. 9 demonstrates the enlarged waveforms of the AC terminal voltage and the input current, respectively. Verifying the results confirms that the output phase voltage $\mathrm{V}_{\mathrm{a}}$ is constant and sinusoidal, during the sag ride-through condition. Additionally, the input current is sinusoidal and in phase with the input voltage, and the number of voltage regions is automatically adjusted to the change of $\mathrm{V}_{\mathrm{m}}$ and a 5level waveform is synthesized on the AC side (see Fig. 9).

Fig. 10 shows the simulated PET input and output current waveforms when the load is non-linear. In this simulation the output is connected to a three-phase load, where the load is constructed from a three-phase diode rectifier, a parallel capacitor $(1 \mathrm{mF})$, and a resistive load $(10 \Omega)$. The top trace shows the inverter input current, which is sinusoidal and in phase with the input voltage, thanks to the CHB rectifier control. The input current is sinusoidal even with $73.96 \%$ THD distorted load current.

The validity of the proposed PET and the designed controllers are verified by experimental results on a laboratory scale prototype. The prototype is a $1500 \mathrm{~W}$, single-phase to three-phase transformer based on a 7level $\mathrm{CHB}$ rectifier. The rated $\mathrm{Ph}-\mathrm{N}$ input and output voltages are 220 and $39 \mathrm{~V} \mathrm{rms}$, respectively. The digital control unit has been implemented based on a TMS 320F2812 DSP controller. Other principal parameters of the prototype are given in Table II.

Table I. Simulation data used for verifying the PET performance

\begin{tabular}{lcc}
\multicolumn{1}{c}{ Parameter } & Symbol & Value \\
\hline Number of series H-bridges at the input & $\mathrm{N}$ & 4 \\
\hline Rated power & $P_{t}$ & $30 \mathrm{~kW}$ \\
\hline Nominal peak input voltage & $V_{m}$ & $2694 \mathrm{~V}$ \\
\hline Primary DC link voltages & $V_{C}$ & $750 \mathrm{~V}$ \\
\hline Secondary DC link voltage & $V_{o}$ & $600 \mathrm{~V}$ \\
\hline Output phase voltages & $V_{a}, V_{b}, V_{c}$ & $220 \mathrm{~V} \mathrm{rms}$ \\
\hline Transformers turn ratio & $m$ & $1: 1$ \\
\hline Steady state Duty cycle & $D$ & 0.4 \\
\hline Sampling frequency & $f_{o}$ & $3 \mathrm{kHz}$ \\
\hline Switching frequency & $f_{s}$ & $15 \mathrm{~Hz}$ \\
\hline
\end{tabular}

Table II. Principal parameters of the scale down prototype

\begin{tabular}{lcc}
\multicolumn{1}{c}{ Parameter } & Symbol & Value \\
\hline Number of series H-bridges at the input & $\mathrm{N}$ & 3 \\
\hline Rated power & $P_{t}$ & $1.5 \mathrm{~kW}$ \\
\hline Nominal peak input voltage & $V_{m}$ & $310 \mathrm{~V}$ \\
\hline Primary DC link voltages & $V_{C}$ & $125 \mathrm{~V}$ \\
\hline Secondary DC link voltage & $V_{o}$ & $100 \mathrm{~V}$ \\
\hline Output phase voltages & $V_{a}, V_{b}, V_{c}$ & $39 \mathrm{~V} \mathrm{rms}$ \\
\hline Transformers turn ratio & $m$ & $1: 1$ \\
\hline Secondary inductors & $\mathrm{L}$ & $220 \mathrm{uH}$ \\
\hline Equivalent series resistance & $\mathrm{R}$ & $0.26 \Omega$ \\
\hline Steady state Duty cycle & $D$ & 0.4 \\
\hline Sampling frequency & $f_{o}$ & $3 \mathrm{kHz}$ \\
\hline Switching frequency & $f_{s}$ & $15 \mathrm{~Hz}$ \\
\hline
\end{tabular}



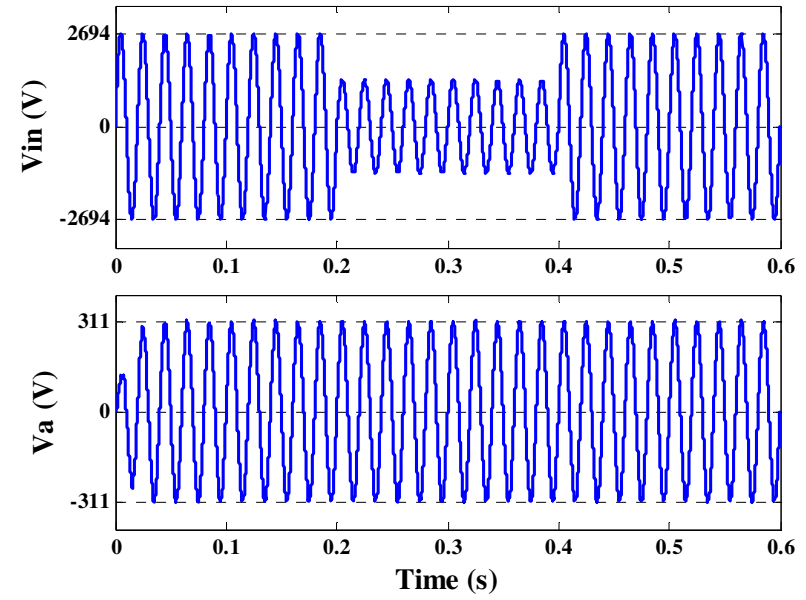

Figure 8. Input voltage (top) and output phase voltage (bottom) during a $50 \%$ sag ride-through

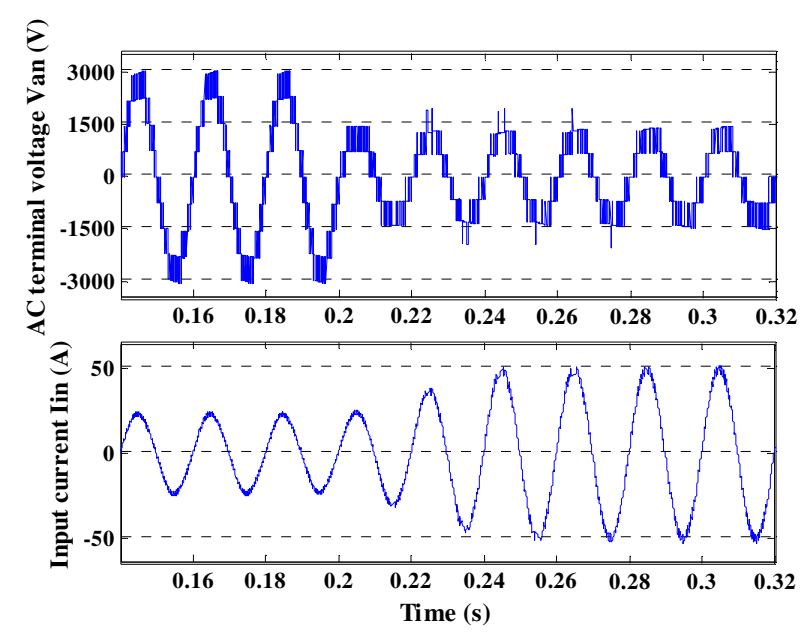

Figure 9. Details of AC terminal voltage and input current when a 50\% voltage sag appears at the primary side

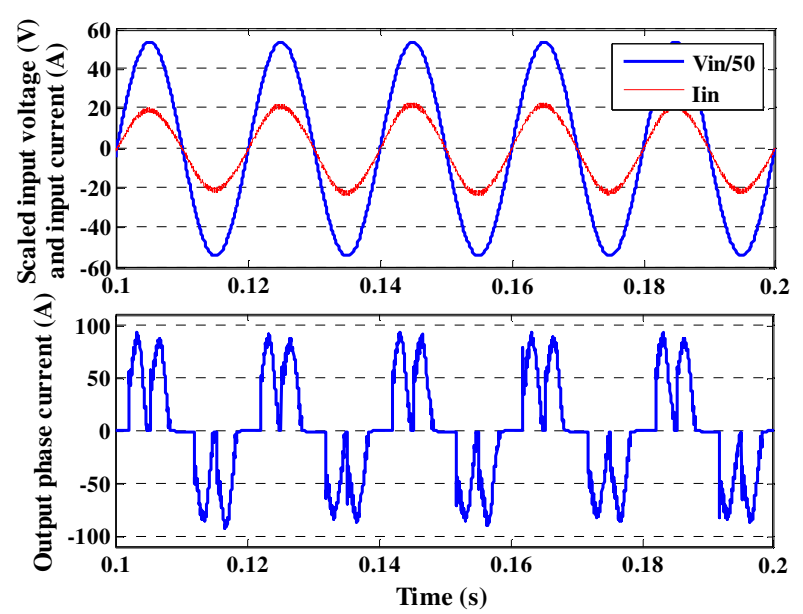

Figure 10. Evaluating PET performance when the load is non-linear: input voltage and current (top) and the output phase current (bottom)

The first experiment investigates the PET performance in steady state and sag ride-through condition. In this experiment, the input voltage reduces $50 \%$ from the rated value and again recovers to the initial

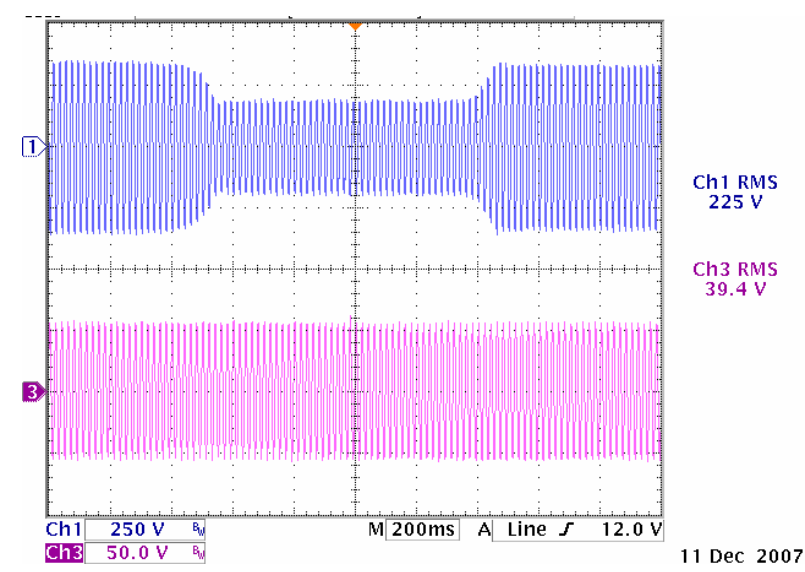

Figure 11. Input voltage (top) and the output voltage (bottom) during $50 \%$ sag ride-through

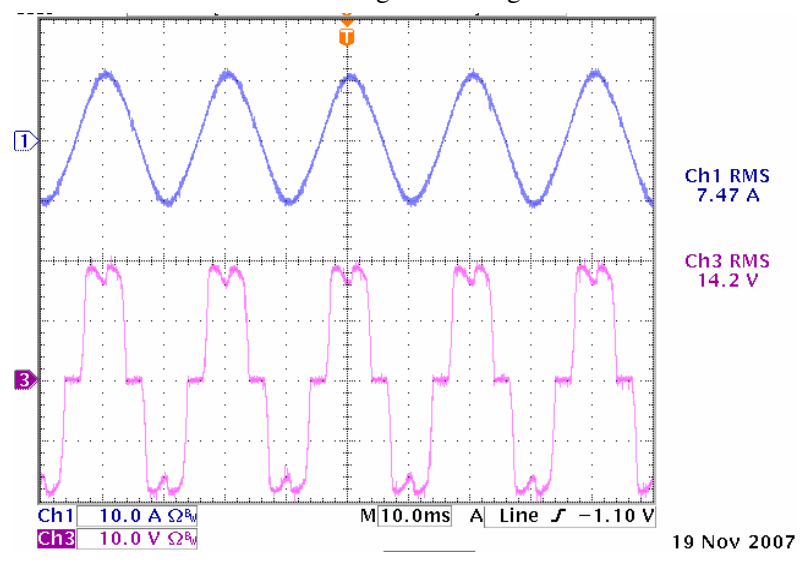

Figure 12. PET performance under non-linear load: input current (top) and the output phase current (bottom)

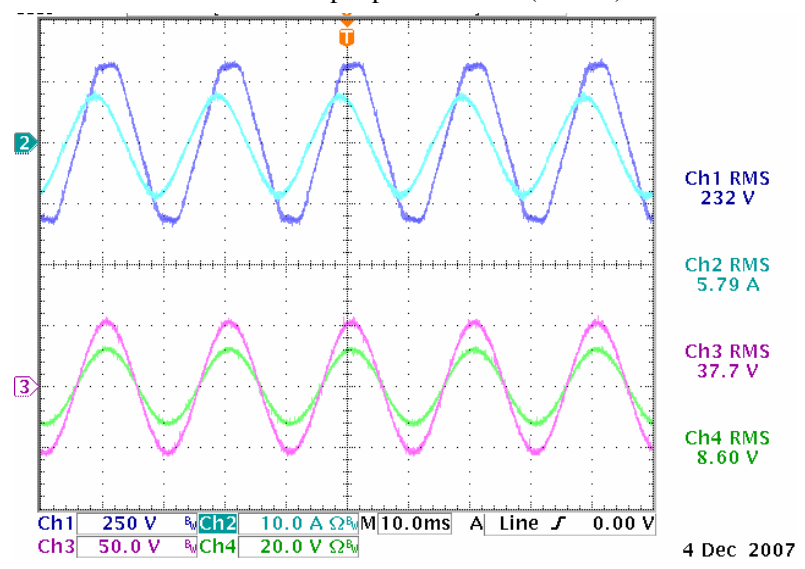

Figure 13. PET as a VAR compensator: input voltage and current waveforms (top) and the output voltage and current curves (bottom)

value after $800 \mathrm{~ms}$. The load power is constant and equal to $1000 \mathrm{~W}$. The corresponding input and output voltage waveforms are shown in Fig. 11.

From Fig. 11, it is observed that the voltage magnitude is kept constant in the load side, regardless of the input voltage variations. Furthermore, during voltage sag condition, the $\mathrm{CHB}$ rectifier try to keep the primary DC link voltages constant, and therefore, maintaining the output voltage constant. 
Fig. 12 illustrates the input and output phase currents when the load is not linear. In this experiment, the nonlinear load is constructed by a three-phase diode rectifier and a resistive load $\left(\mathrm{P}_{\text {in }}=1700 \mathrm{~W}\right)$. The current waveforms in Fig. 12 confirm that the input current is sinusoidal and has a unity power factor, regardless of the output current wave-shape. With the closed-loop control, the output voltage is also maintained sinusoidal under non-linear load condition. The THD of the input current, output voltage, and output current are $3.9 \%, 7.8 \%$, and $31 \%$, respectively.

The last experiment verifies the PET capability in reactive power compensation. As it can be seen form Fig. 13, the line current leads the input voltage with the power factor $\mathrm{PF}_{\mathrm{in}}=0.8$. In this case, $\mathrm{PET}$ injects $750 \mathrm{VA}$ reactive power to the input line and absorbs $1000 \mathrm{~W}$ active power from it.

It is worth noting that the overall efficiency of the PET, described herein, is close to $90 \%$. To achieve greater efficiencies in a PET, soft switching could be employed to reduce the switching losses in the isolation and output stages. Further, as the capacity is increased, the overall system efficiency should rise since the controls and other overhead would consume a decreasing amount of the input power [5]. Higher efficiencies are expected for the optimized design and implementation at actual voltage levels.

\section{CONCLUSION}

In this paper a modular structure of PE based transformer was introduced. The modular structure of the PET guarantees an easy and fast adaptation of different voltage systems with different power frequencies. In comparison with the conventional transformers, PET has light weight, small volume, extended functionality, and eliminates the necessity for toxic dielectric coolants. PET integrates several PQ functions into a single device, besides the typical functions. It mitigates voltage sag, swell, voltage flicker, and performs power factor correction either in input or output side. Further, it can inject reactive power into mains and protect the load from momentary input power disturbances. Considering the enhanced functionality and flexibility of PET, the added cost can be easily justified. It is likely that the PET will have a major impact on the utility industry and the places such as aircraft and shipboard where the high quality power conversion is very desirable [7].

\section{REFERENCES}

[1] S. Srinivasan and G. Venkataramanan, "Comparative evaluation of PWM AC-AC converters," in proc. IEEE Power Electronic Specialist Conference, PESC 1995, vol. 1, pp. 529535, June 1995.

[2] K. Harada, F. Anan, K. Yamasaki, M. Jinno, Y. Kawata, and T. Nakashima, "Intelligent transformer," in proc. IEEE Power Electronic Specialist Conference, PESC 1996, vol. 2, pp. 1337 1341, June 1996.

[3] M. Kang, P.N. Enjeti, and I.J. Pitel, "Analysis and design of electronic transformers for electric power distribution systems," in IEEE Trans. on Power Electronics, vol. 14, no.6, pp. 1133-1141, Nov. 1999.

[4] H. Krishnaswami and V. Ramanarayanan, "Control of highfrequency ac link electronic transformer," in.IEE Electric Power Applications, vol. 152, no. 3, pp. 509- 516, May 2005.

[5] E.R. Ronan, S.D. Sudhoff, S.F. Glover, and D.L. Galloway, “A power electronic-based distribution transformer," IEEE Trans. on Power Delivery., vol.17, pp. 537 - 543, April 2002.

[6] H. Iman-eini and Sh. Farhangi, "Analysis and design of power electronic transformer for medium voltage levels," in proc. IEEE Power Electronic Specialist Conference, PESC 2006, pp. 1- 5, June 2006.

[7] J.S. Lai, A. Maitra, A. Mansoor, and F. Goodman, "Multilevel intelligent universal transformer for medium voltage applications," in Proc. IEEE Industry Applications Conf., Vol. 3, pp. 1893 - 1899, October 2005.

[8] D. Gerry, P. Wheeler, and J. Clare, "High-voltage multicellular converters applied to ac/ac conversion,” International journal of electronics, vol. 90, no. 11-12, pp. 751-762, 2003.

[9] M. Glinka and R. Marquardt, "A new ac/ac multilevel converter family," in IEEE Trans. on Industrial Electronics, vol. 52, no. 3, pp. 662- 669, June 2005.

[10] A. Rufer, N. Schibli, C. Chabert, and C. Zimmermann, "Configurable front-end converters for multicurrent locomotives operated on $162 / 3 \mathrm{~Hz}$ ac and $3 \mathrm{kV}$ dc systems," in IEEE Trans. on Power Electronics, vol. 18, no. 5, pp. 11861193, September 2003.

[11] L. Heinemann, “ An actively cooled high power, high frequency transformer with high insulation capability," in IEEE Applied Power Electronics Conf., APEC 2002, vol. 1, pp. 352357, March 2002.

[12] D. Wang, C. Mao, J. Lu, S. Fan, and F. Peng, "Theory and application of distribution electronic power transformer, " Electric Power System Research Journal, vol.77, Issues 3-4, pp. 219 - 226, March 2007.

[13] H. Iman-Eini, J-L. Schanen, Sh. Farhangi, and S. Wabg, "Design of Cascaded H-Bridge Rectifier for Medium Voltage Applications," in proc. IEEE PESC conf., pp. 653- 658, June 2007.

[14] H. Iman-Eini, Sh. Farhangi, and J-L. Schanen, "A modular ac/dc rectifier based on cascaded H-bridge rectifier," to be presented at the $13^{\text {th }}$ International Power Electronics and Motion Control conf., EPE - PEMC 2008, Poznan, Poland, Sep. 2008. 